3. Lewandowski K. Extracorporeal membrane oxygenation for severe acute respiratory failure. Crit Care. 2000;4:156-68.

4. Petrof BJ, Legare M, Goldberg P, Milic-Emili J, Gottfried SB. Continuous positive airway pressure reduces work of breathing and dyspnea during weaning from mechanical ventilation in severe chronic obstructive pulmonary disease. Am Rev Respir Dis. 1990;141:281-9.

5. Yang KL, Tobin MJ. A prospective study of indexes predicting the outcome of trials of weaning from mechanical ventilation. N Engl J Med. 1991;324:1445-50.

\title{
A case of Sjögren's syndrome leading to mitral and aortic valve replacement
}

\author{
Kevin Bridge, MD, MSPH, and Robert Saeid Farivar, MD, PhD, Iowa City, Iowa
}

A 62-year-old woman presented with dyspnea on exertion, and an echocardiogram demonstrated an ejection fraction of $55 \%$ to $60 \%$, severe mitral regurgitation, and moderate aortic regurgitation. The patient had rheumatic disease as a child, and her valve failure was presumed to be due to rheumatic disease sequelae. She previously had an axillary lymph node biopsy for adenopathy at an outside hospital and was thought to have Castleman's disease. At the University of Iowa Heart and Vascular Center, she underwent aortic and mitral valve replacement through a full sternotomy and bicaval cannulation. The aortic valve was replaced with a 21-mm Magna ThermaFix Edwards bovine pericardial valve (Edward Lifesciences, Irvine, Calif). The mitral valve was replaced with a 29-mm St Jude Epic porcine valve (St Jude Medical Inc, St Paul, Minn). Intraoperatively, the pericardium was found to be inflamed and adherent to the aorta and right ventricle. The native aortic valve was trileaflet, and both valves were rubbery in consistency with significant nodules present. The leaflets were friable. No calcification was found on the mitral annulus. The mitral valve was not repairable.

The gross pathology showed tan white nodules, $0.3 \mathrm{~cm}$ in the greatest dimensions, with spiculated appendages on the surface of the valves. The microscopic pathology demonstrated fibroelastic tissue with focal palisading and noncaseating granulomatous inflammation with central necrosis (Figure 1). Postoperative recovery was uneventful. The patient underwent multiple serologic tests that suggested a diagnosis of Sjögren's syndrome (Table 1), which was

\footnotetext{
From the Department of Cardiothoracic Surgery, University of Iowa Hospitals and Clinics, Carver College of Medicine, University of Iowa Heart and Vascular Center, Iowa City, Iowa.

Disclosures: None.

Received for publication Sept 13, 2009; accepted for publication Nov 28, 2009; available ahead of print Feb 22, 2010.

Address for reprints: Robert Saeid Farivar, MD, PhD, University of Iowa, Cardiothoracic Surgery, 200 Hawkins Dr, SE517GH, Iowa City, IA 52242-1062 (E-mail: robert-farivar@Uiowa.edu).

J Thorac Cardiovasc Surg 2010;139:e139-40

0022-5223/\$0.00

Published by Elsevier Inc. on behalf of The American Association for Thoracic Surgery

doi:10.1016/j.jtcvs.2009.11.068
}

confirmed with a positive Schirmer's test and a labial salivary gland biopsy.

\section{DISCUSSION}

Sjögren's syndrome was first identified in 1933 by Dr Henrik Sjögren and is a chronic autoimmune disorder with lymphocytic infiltration of the exocrine glands. Sjögren's syndrome manifests with sicca symptoms, including xerophthalmia and xerostomia. This disease primarily affects women, and most cases are diagnosed during the middleage years. Sjögren's syndrome occurring without any other manifestation of other autoimmune diseases has been labeled as primary Sjögren's syndrome. Secondary Sjögren's

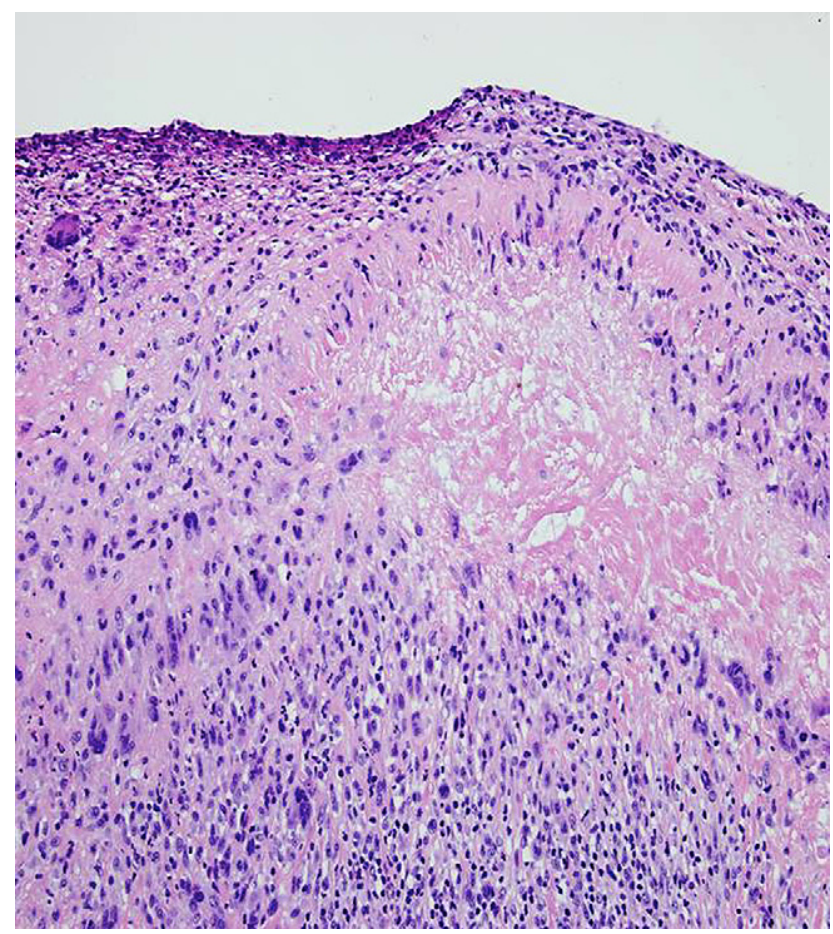

FIGURE 1. Mitral valve leaflet pathology demonstrating palisading and granulomatous inflammation, $200 \times$. 
TABLE 1. Serologic testing results

\begin{tabular}{|c|c|c|}
\hline Test & Result & Normal range \\
\hline C-reactive protein & $4.6(\mathrm{H})$ & $0-20 \mathrm{~mm} / \mathrm{h}$ \\
\hline $\begin{array}{l}\text { Erythrocyte sedimentation } \\
\text { rate }\end{array}$ & $55(\mathrm{H})$ & $<0.5 \mathrm{mg} / \mathrm{dL}$ \\
\hline Rheumatoid factor & $38(\mathrm{H})$ & $<14 \mathrm{IU} / \mathrm{mL}$ \\
\hline SSA antibody & $127(\mathrm{H})$ & $<19$ units \\
\hline SSB antibody & $182(\mathrm{H})$ & $<19$ units \\
\hline Anti-nuclear antibody titer & $>1: 2560(\mathrm{H})$ & $<1: 40$ \\
\hline $\begin{array}{l}\text { Double-stranded DNA } \\
\text { antibody }\end{array}$ & $423(\mathrm{H})$ & 0-200 IU/mL \\
\hline Anti-RNP antibody & $59(\mathrm{H})$ & 0-19 units \\
\hline IgG, serum & $2337(\mathrm{H})$ & $694-1618 \mathrm{mg} / \mathrm{dL}$ \\
\hline ANCA screen & Negative & \\
\hline Antistreptolysin $\mathrm{O}$ & $<55$ & 0-330 IU/mL \\
\hline $\begin{array}{l}\text { Anti-cyclic citrullinated } \\
\text { peptide }\end{array}$ & 4 & 0-19 units \\
\hline C3 complement & 151 & $90-180 \mathrm{mg} / \mathrm{dL}$ \\
\hline C4 complement & 18 & $16-47 \mathrm{mg} / \mathrm{dL}$ \\
\hline Anti-Smith antibody & 5 & $0-19$ units \\
\hline IgM, serum & 89 & $60-263 \mathrm{mg} / \mathrm{dL}$ \\
\hline IgA, serum & 335 & $68-378 \mathrm{mg} / \mathrm{dL}$ \\
\hline $\begin{array}{l}\text { Angiotensin-1-converting } \\
\text { enzyme }\end{array}$ & 16 & $8-52 \mathrm{U} / \mathrm{L}$ \\
\hline
\end{tabular}

$R N P$, Ribonucleoprotein; $S S A$, Sjögren's syndrome A; SSB, Sjögren's syndrome B; $A N C A$, anti-neutrophil cytoplasmic antibody; $I g$, immunoglobulin. High $(\mathrm{H})$ is denoted in the result column, as is the normal reference range at the University of Iowa Heart and Vascular Center.

syndrome occurs when associated with another autoimmune connective tissue disease, such as rheumatoid arthritis, systemic lupus erythematosus, or scleroderma. Primary and secondary Sjögren's syndromes occur with approximately equal frequency. ${ }^{1}$ In addition to the salivary and lacrimal glands, Sjögren's syndrome often affects other organ systems, including the gastrointestinal tract, skin, lungs, vasculature, kidneys, bladder, and vagina. ${ }^{2}$

Mitral valve replacement for Sjogren's syndrome has not been previously reported. Previous studies have reported echographic findings of valvular regurgitation and pericardial effusion in patients with primary Sjögren's syndrome. ${ }^{3}$ There has been 1 previous case report of a patient with Sjögren's syndrome associated with aortic valve regurgitation who underwent aortic valve replacement for infective endocarditis. ${ }^{4}$ This is the first report of double-valve replacement in connection with Sjögren's syndrome. A previous report documented a patient with similar characteristics to our patient, including age, gender, medical history, and clinical symptoms on presentation. The patient was found to have mitral and aortic valve stenosis. Further workup showed the patient to be rheumatoid factor positive, antinuclear antibody positive, and Sjögren syndrome A positive. The patient underwent a Schirmer's test and a salivary gland biopsy to confirm a diagnosis of Sjögren's syndrome. The patient refused surgical treatment and was treated with prednisolone therapy. Her symptoms reportedly improved, although the valve lesions remained. ${ }^{5}$ To our knowledge, there has been no previous documentation of cardiac valvular failure requiring double-valve replacement in connection with primary Sjögren's syndrome. In addition, this is the initial report of insufficiency in Sjogren's syndrome being treated with valve replacement.

\section{CONCLUSIONS}

Pathology indicated a nonrheumatic autoimmune connective tissue disease for which the differential diagnosis includes Sjögren's syndrome, systemic lupus erythematosus, mixed connective tissue disorder, and undifferentiated connective tissue disorder. This type of pathology is seen in connection with rheumatoid arthritis, which is a form of a connective tissue disorder, but the patient does not have any clinical symptoms of rheumatoid arthritis. Laboratory evidence supports a diagnosis of a connective tissue disorder. The patient was found to have high antinuclear antibody, Sjögren syndrome A and B, and anti-ribonucleoprotein titers, suggesting a diagnosis of Sjögren's syndrome or systemic lupus erythematosus. Sequelae of childhood rheumatic fevers cause valvular dysfunction, but the typical calcifications, valve thickening and fusion of the commissures typically seen in conjunction with rheumatic fever, were not observed. Sarcoidosis is a possible diagnosis based on bihilar lymphadenopathy and the presence of noncaseating granulomas on the patient's native valves, although serologic tests did not support this diagnosis. Infectious causes are other possible causes or valvular dysfunction, although no infectious organisms were identified.

\section{References}

1. Manoussakis MN, Georgopoulou C, Zintzaras E, Spyropoulou M, Stavropoulou A, Skopouli FN, et al. Sjögren's syndrome associated with systemic lupus erythematosus: clinical and laboratory profiles and comparison with primary Sjögren's syndrome. Arthritis Rheum. 2004;50:882-91.

2. Lee BH, Tudares MA, Nguyen CQ. Sjögren's syndrome: an old tale with a new twist. Arch Immunol Ther Exp. 2009;57:57-66.

3. Vassiliou VA, Moyssakis I, Boki KA, Moutsopoulos HM. Is the heart affected in primary Sjögren's syndrome? An echocardiographic study. Clin Exp Rheumatol. 2008;26:109-12.

4. Sughimoto K, Nakano K, Gomi A, Nakatani H, Nakamura Y, Sato A. Infective endocarditis associated with Sjögren's syndrome. Asian Cardiovasc Thorac Ann. 2006; $14: 115-7$.

5. Tsuji M, Nakatani T, Nojiri T, Nishio H, Shima H, Hiroi Y, et al. A case of Sjögren's syndrome with valvular diseases. Jpn Heart J. 1986;27:137-43. 